\title{
Cross cultural child injury prevention awareness
}

\author{
Dale O Ritzel, Klaus Klein, Julie Gast, Paul D Sarvela
}

\begin{abstract}
Purpose-The purpose of this study was to determine how injury prevention awareness of children ages 3,4 , and 5 , based on recognition of hazards in pictures differs in the United States, Belgium, East Germany and West Germany.

Methods-Children from these four countries were presented with 10 different pictures. Each picture represented a common injury producing situation to which children are exposed in traffic, home, and recreation.
\end{abstract}

Results-Results indicate that for pictures relating to home hazards, less than $22 \%$ of children from Belgium (21.5\%), West Germany $(4 \cdot 7 \%)$, and the United States $(20.3 \%)$ clearly recognized the essential hazards in the pictures, whereas over $40 \%$ of the East German children clearly recognized these dangers. A higher proportion of the children from all countries recognized the traffic hazards. Only $23.9 \%$ of all children had a clear recognition of the playground situations. The child's age had a bearing on ability to recognize hazards overall.

Conclusions-Children need to be provided with better injury prevention education at an early age, especially those from West Germany.

(Injury Prevention 1996; 2: 44-46)

Keywords: hazard recognition, cross cultural injury prevention awareness.

Center for Injury

Control and Worksite Health Promotion, Southern Illinois University, Carbondale, IL 62901, USA DO Ritzel

Health Education Research Unit, University of Cologne, Cologne, Germany K Klein

Department of Health, Physical Education, and Recreation, Utah State University, Logan, Utah, USA J Gast

Center for Rural Health and Social Service Development, Southern Illinois University, Carbondale, Illinois, USA

PD Sarvela

Correspondence and reprint requests to: Professor Ritzel.

Fatal injury rates were lowest for Asians and whites, while rates were three times higher for black children as for white children. Drownings were twice as high, however, for white children as for black children. ${ }^{3}$

Other studies have noted similar relationships. A literature review found that boys under 5 years were more likely to die from injuries than girls of the same age. ${ }^{4}$ This same review found that younger children were more likely to die or be injured from choking, suffocation, and poisoning, whereas, primary grade children were more likely to die or be hurt from pedestrian injuries.

Often socioeconomic variables place children at increased risk. Lower educational attainment of parents and lower income levels correlate with higher injury and fatality rates. ${ }^{45}$ Other research has found children from single parent homes, or homes where step parents are present, or of low maternal age to be at higher risk. ${ }^{5}$

An important step in developing injury prevention materials and programs is to determine the knowledge and skill level of the target population while also determining its epidemiologic characteristics. A content analysis of the educational media evaluation of 49 safety programs from four state health departments was conducted to determine if the focus of materials matched current trends in the occurrence of childhood injuries. ${ }^{6}$ This evaluation found that the safety media failed to meet the injury prevention needs of children when compared with the top seven causes of death. Also, many safety messages only demonstrated the unwanted behavior. ${ }^{6}$

Other studies have examined rewarding children who perform desired behaviors but found that the safety behavior rates decrease after the rewards stop. ${ }^{7}$ Often injury prevention programs for children fail to change behavior because the teachings conflict with parental assumptions or the belief by parents that their child is not at risk for injury. ${ }^{8}$

Materials for children need to be simple and direct and emphasize 'how-to' instructions of safe behaviors. ${ }^{9}$ Injury prevention programs in the United States often fail to change behavior, because materials do not match the developmental needs of the child. Materials, such as pictures, need to be developed and assessed, so researchers and educators can determine their usefulness in developing teaching-learning tools for preparing children in combating potential hazards in real-world situations.

The purpose of this study was to determine how injury prevention awareness of children ages 3,4 , and 5 differ in four countries when the children examined hazards in 10 pictures that depict a variety of home, traffic, and play activities.

\section{Methods}

A total of 234 children from the United States $(n=60)$, Belgium $(n=60)$, former East Germany $(n=54)$, and former West Germany $(n=60)$ were selected for this study. Data were collected in early 1992 from children attending 
nursery schools or day care centers. Each child was presented with 10 different pictures representing common dangers to which he or she might be exposed in traffic, at home, and during recreational activities.

Each child was shown the 10 pictures one after the other and was asked to describe what they saw (see table 1). Interviewers were instructed not to probe for answers nor were they allowed to inform the children what they should be looking for - that is, the potential hazard. If a child did not give a response to a picture, the interviewer went on to the next.

Responses were translated and $10 \%$ were rechecked for accuracy of translation by a second translator. The inter-rater reliability of the translation was $100 \%$. Responses were also coded on a four point scale with four indicating the child made no response to a picture, three indicating that the child did not identify any potential hazard, two indicating partial recognition of a hazard(s), and one indicating a clear recognition of one or more potential hazard(s). Inter-rater reliability on these codes was $85 \%$, and intrarater reliability was $97 \%$.

The $\chi^{2}$ test was used to determine if the country groups had statistically significantly different responses to the pictures. A significance level of $p<0.01$ was set before data analysis.

\section{Results}

Results indicated that children from East Germany were far better in recognizing hazards than children from the other countries (see

Table 1 Contents of 10 pictures of home, traffic, and recreational safety hazard scenes

\begin{tabular}{lll}
\hline Picture Noo & Picture depiction & Context \\
\hline 1 & $\begin{array}{l}\text { Girl on stairs with saw } \\
\text { Family at table with girl } \\
\text { leaning in chair } \\
\text { Girl standing on window ledge } \\
\text { looking out } \\
\text { Girl baking cookies with sharp } \\
\text { knife on table }\end{array}$ & $\begin{array}{l}\text { Home } \\
\text { Home }\end{array}$ \\
3 & $\begin{array}{l}\text { Helt belted girl in car: stuffed } \\
\text { toy in car seat next to girl }\end{array}$ & Traffic \\
5 & $\begin{array}{c}\text { Girl on bed with hazardous } \\
\text { item (scissors, hair dryer, } \\
\text { electric fan, etc) }\end{array}$ & Home \\
7 & $\begin{array}{l}\text { Girl falling off teeter-totter } \\
\text { Girl and boy playing with } \\
\text { fireworks outside }\end{array}$ & Recreational \\
8 & $\begin{array}{c}\text { Girl in kitchen trying to } \\
\text { touch hot pot }\end{array}$ & Home \\
9 & $\begin{array}{c}\text { Girl and boy running across } \\
\text { street with car nearby }\end{array}$ & Traffic \\
\hline
\end{tabular}

table 2). Statistically significant differences existed among the four countries across all 10 pictures.

The data also revealed that, overall, for the pictures relating to home hazards (pictures 1,2, $3,4,6$, and 9 ), only $21.5 \%$ of the Belgian children clearly recognized the hazards, $4 \cdot 7 \%$ of the West German children, and $20.3 \%$ of the United States children. Of home hazards' pictures, $40 \cdot 7 \%$ of the East Germans did clearly recognize hazards. A higher proportion of children from all countries recognized the hazards relating to traffic (pictures 5 and 10). West German children however had the least recognition of the potential hazards.

Only $23.9 \%$ of the children had a clear recognition of the dangers in the playground situation (picture 7). The hazards in the other recreation related picture (number 8) were clearly recognized by $18.8 \%$ of the children in all countries.

A statistically significant difference was found $\left(\chi^{2}=11.97, p<0.003\right)$ in the ability of children to clearly recognize hazards in the home $(21 \%)$, recreation $(26 \%)$, and traffic $(28 \%)$ pictures.

Overall, girls (12.2\% v $11.6 \%$ for boys) were more successful in clearly spotting the hazards, although no statistically significant difference occurred between boys and girls across all pictures.

As expected, age was related to accurate hazard recognition (see table 3 ). In almost all cases, 5 year olds clearly recognized hazards twice as often as the 4 year olds, and between three and 10 times more often than the 3 year olds.

\section{Discussion}

A review of related literature suggests that this is the first study to compare hazard awareness of children by country. Initially, children in United States, West Germany, and Belgium were assumed to be better able to select potential hazards than those from East Germany, because of educational and training exposures that children in the first three countries would have. Unexpectedly, children from East Germany, however, proved far more capable of clearly recognizing the hazards in these pictures.

Why children from East Germany. more often identified hazards than children from the other countries is not yet clear. In most families

Table 2 Frequency, percentage, and $\chi^{2}$ analysis of clear recognition of safety hazards by country and by picture

\begin{tabular}{|c|c|c|c|c|c|c|c|c|c|}
\hline \multirow[b]{2}{*}{ Picture No } & \multicolumn{2}{|c|}{ East Germany $(n=54)$} & \multicolumn{2}{|c|}{ West Germany $(n=60)$} & \multicolumn{2}{|c|}{ Belgium $(n=60)$} & \multicolumn{2}{|c|}{ United States $(n=60)$} & \multirow[b]{2}{*}{$\chi^{2}$} \\
\hline & $\%$ & No & $\%$ & No & $\%$ & No & $\%$ & No & \\
\hline $\begin{array}{l}1 \\
2 \\
3 \\
4 \\
5 \\
6 \\
7 \\
8 \\
9 \\
10\end{array}$ & $\begin{array}{l}33 \cdot 3 \\
50 \cdot 0 \\
53 \cdot 7 \\
27 \cdot 8 \\
44 \cdot 4 \\
33 \cdot 3 \\
48 \cdot 2 \\
55 \cdot 6 \\
46 \cdot 3 \\
61 \cdot 1\end{array}$ & $\begin{array}{l}18 \\
27 \\
29 \\
15 \\
24 \\
18 \\
26 \\
30 \\
25 \\
33\end{array}$ & $\begin{array}{r}1.7 \\
3.3 \\
13.3 \\
0.0 \\
16.7 \\
0.0 \\
5.0 \\
10.0 \\
10.0 \\
23.3\end{array}$ & $\begin{array}{r}1 \\
2 \\
8 \\
0 \\
10 \\
0 \\
3 \\
6 \\
6 \\
14\end{array}$ & $\begin{array}{r}16 \cdot 7 \\
16.7 \\
33.3 \\
6.7 \\
3.3 \\
16 \cdot 7 \\
30.0 \\
36.7 \\
38.3 \\
55.0\end{array}$ & $\begin{array}{r}10 \\
10 \\
20 \\
4 \\
2 \\
10 \\
18 \\
22 \\
23 \\
33\end{array}$ & $\begin{array}{r}31 \cdot 7 \\
30 \cdot 0 \\
11 \cdot 7 \\
16 \cdot 7 \\
6 \cdot 7 \\
13 \cdot 3 \\
15 \cdot 0 \\
15 \cdot 0 \\
18 \cdot 3 \\
21 \cdot 7\end{array}$ & $\begin{array}{r}19 \\
18 \\
7 \\
10 \\
4 \\
8 \\
9 \\
9 \\
11 \\
13\end{array}$ & $\begin{array}{l}23 \cdot 64^{\star} \\
36 \cdot 63^{\star} \\
33 \cdot 32^{\star} \\
23 \cdot 08^{\star} \\
41 \cdot 13^{\star} \\
24 \cdot 54^{\star} \\
33 \cdot 05^{\star} \\
36 \cdot 70^{\star} \\
24 \cdot 68^{\star} \\
31 \cdot 06^{\star}\end{array}$ \\
\hline
\end{tabular}

${ }^{\star} \mathrm{p}<0.001, \mathrm{df}=3$. 
Table 3 Frequency, percentage, and $\chi^{2}$ analysis of clear recognition of safety hazards by age and by picture

\begin{tabular}{|c|c|c|c|c|c|c|c|c|}
\hline \multirow[b]{2}{*}{ Picture No } & \multicolumn{2}{|c|}{3 years } & \multicolumn{2}{|c|}{4 years } & \multicolumn{2}{|c|}{5 years } & \multirow[b]{2}{*}{$\chi^{2}$} & \multirow[b]{2}{*}{ p Value } \\
\hline & $\%$ & No & $\%$ & No & $\%$ & No & & \\
\hline $\begin{array}{l}1 \\
2 \\
3 \\
4 \\
5 \\
6 \\
7 \\
8 \\
9 \\
10\end{array}$ & $\begin{array}{r}13.2 \\
10.5 \\
13.2 \\
2.6 \\
4.0 \\
7.9 \\
11.8 \\
10.5 \\
11.8 \\
22.4\end{array}$ & $\begin{array}{r}10 \\
8 \\
10 \\
2 \\
3 \\
6 \\
9 \\
8 \\
9 \\
17\end{array}$ & $\begin{array}{r}18 \cdot 0 \\
19 \cdot 2 \\
23 \cdot 1 \\
9 \cdot 0 \\
16 \cdot 7 \\
10 \cdot 3 \\
19 \cdot 2 \\
23 \cdot 1 \\
20 \cdot 5 \\
34 \cdot 6\end{array}$ & $\begin{array}{r}14 \\
15 \\
18 \\
7 \\
13 \\
8 \\
15 \\
18 \\
16 \\
27\end{array}$ & $\begin{array}{l}30 \cdot 4 \\
41 \cdot 8 \\
45 \cdot 6 \\
25 \cdot 3 \\
29 \cdot 1 \\
27 \cdot 9 \\
40 \cdot 5 \\
51 \cdot 9 \\
50 \cdot 6 \\
62 \cdot 0\end{array}$ & $\begin{array}{l}24 \\
33 \\
37 \\
20 \\
23 \\
22 \\
32 \\
41 \\
40 \\
49\end{array}$ & $\begin{array}{l}19.43 \\
42.52 \\
31.68 \\
23.07 \\
31.90 \\
17.82 \\
37.25 \\
53.07 \\
41.23 \\
30.66\end{array}$ & $\begin{array}{l}0.003 \\
0.001 \\
0.001 \\
0.001 \\
0.001 \\
0.007 \\
0.001 \\
0.001 \\
0.001 \\
0.001\end{array}$ \\
\hline
\end{tabular}

under communist rule, both parents worked. Child care was provided by the government, and structured educational and cultural programs were provided during the child's stay in day care. It is also possible that when both parents are working, children develop more independence and are more able to take care of themselves, including being aware of the environment around them.

\section{IMPLICATIONS FOR PREVENTION}

Based on these findings it is reasonable to suggest that local communities in each of the countries must target preventive interventions to the community, caregiver, and child. ${ }^{8}$ Child injury prevention programs should teach parents about the leading causes of injuries. As much as possible, community programs should also provide parents and children with strategies to avoid and prevent injuries.

Injury prevention programs should also be directed at caregivers who can help children gain knowledge about hazards. If travel is provided with the child care, younger children can be placed in child safety seats. As they get older, a child can be shown how to properly buckle up. In the end, however, our findings suggest that injury prevention programs must target children directly. They should address the full range of situations presented in this study, and provide opportunities to practice injury prevention skills.

1 National Safety Council. Accidents facts. Itasca, IL National Safety Council, 1995.

2 Guyer B, Gallagher SS, Chang B, Azzara CV, Cupples LA Colton T. Prevention of childhood injuries: evaluation of the statewide childhood injury prevention program (SCIPP). Am F Public Health 1989; 79: 1521-7.

3 Waller AE, Baker SP, Szocka A. Childhood injury deaths: national analysis and geographic variations. Am $\mathcal{f}$ Public Health 1989; 79: 310-5.

4 Finn-Stevenson $M$, Stevenson JJ. Child care as a site for injury prevention. Children Today 1990; March-April: $17-20,32$.

5 Rivara FP, Mueller BA. The epidemiology and causes of childhood injuries. Fournal of Social Issues 1987; 43: 13-31.

6 Heinsohn S, Ginsbug HJ, Sanchez YB, Mendez R, Arocen $M$, Adams EV. Childhood injury prevention media: past problems and new directions. International fournal of Instructional Media 1992; 19: 1-5.

7 Roberts MC, Fanurik D, Layfield DA. Behavioral approaches to prevention of chldhood injuries. Fournal of Social Issues 1987; 43: 105-18.

8 Garvarino J. Preventing childhood injury: developmenta and mental health issues. Am $\mathcal{F}$ Orthopsychiatry 1988; 58 $25-45$.

9 Race KEH. Evaluating pedestrian safety education materials for children ages five to nine. $\mathcal{F}$ Sch Health 1988 ; 58: 277-81.

\section{A fable: epidemiology and statistics}

There was once a group of biostatisticians and a group of epidemiologists riding together on a train to joint meetings. All the epidemiologists had tickets, but the biostatisticians only had one ticket between them. Inquisitive by nature, the epidemiologists asked the biostatisticians how they were going to get away with such a small sample of tickets when the conductor came through. The biostatisticians said, 'Easy. We have methods for dealing with that'.

Later, when the conductor came to punch tickets, all the biostatisticians slipped quietly into the bathroom. When the conductor knocked on the door, the head biostatistician slipped their one ticket under the door thoroughly fooling the layman conductor.

After the joint meetings were over, the biostatisticians and the epidemiologists again found themselves on the same train. Always quick to catch on, the epidemiologists had purchased one ticket between them. The biostatisticians (always on the cutting edge) had purchased No tickets for the trip home. Confused, the epidemiologist asked the biostatisticians 'We understand how your methods worked when you had one ticket but how can you possibly get away with no tickets?' 'Easy', replied that biostatisticians smugly, 'We have different methods for dealing with that situation'

Later, when the conductor was in the next car, all the epidemiologists trotted off to the bathroom with their one ticket and all the biostatisticians packed into the other bathroom. Shortly, the head biostatistician crept over to where the epidemiologists were hiding and knocked authoritatively on the door. As they had been instructed, the epidemiologists slipped their one ticket under the door. The head biostatistician took the epidemiologists' one and only ticket and returned triumphantly to the biostatistician group. Of course, the epidemiologists were subsequently discovered and publicly humiliated.

Moral of the story. Do not use statistical methods unless you understand the principles behind them (Marion Nadel, Epidemiology L Listserver). 